\title{
On the Ambivalence of the Aphorism in Sociological Theory
}

\author{
Thomas Crosbie, Royal Danish Defence College
}

$\&$

Jeffrey Guhin, UCLA ${ }^{1}$

\begin{abstract}
Sociologists have long been taken by certain pithy expressions from the founders of the discipline. We propose here both a new explanation for the endurance of these statements as well as an analysis of the power, limitations, and possibilities of aphorisms. By drawing from the critical scholarship concerned with aphorisms, we demonstrate that some of the allure of the classical sociological texts derives from their form, and particularly their reliance on the relative autonomy of the aphorism. Through examining Marx's "opiate of the people," Weber's "iron cage," and, briefly, two more contemporary sociological aphorisms, we suggest that aphorisms have an ambivalent role in sociological theory: they make claims memorable even as they potentially oversimplify complex arguments. Yet that very simplification can provide a point of focus for productive misreading and reinterpretation.
\end{abstract}

\section{Keywords}

Aphorisms; classical sociology; rationality; rhetoric; social theory; Weber; Marx

\footnotetext{
${ }^{1}$ This article is fully co-authored.
} 


\title{
On the Ambivalence of the Aphorism in Sociological Theory
}

\author{
Abstract \\ Sociologists have long been taken by certain pithy expressions from the founders of the \\ discipline. We propose here both a new explanation for the endurance of these statements \\ as well as an analysis of the power, limitations, and possibilities of aphorisms. By \\ drawing from the critical scholarship concerned with aphorisms, we demonstrate that \\ some of the allure of the classical sociological texts derives from their form, and \\ particularly their reliance on the relative autonomy of the aphorism. Through examining \\ Marx's “opiate of the people," Weber's "iron cage," and, briefly, two more contemporary \\ sociological aphorisms, we suggest that aphorisms have an ambivalent role in \\ sociological theory: they make claims memorable even as they potentially oversimplify \\ complex arguments. Yet that very simplification can provide a point of focus for \\ productive misreading and reinterpretation.
}

\section{Keywords}

Aphorisms; classical sociology; rationality; rhetoric; social theory; Weber; Marx 


\section{Introduction}

Many leading figures in the history of modern social thought have expressed some or even most of their reflections in brief epigrams rather than elaborated arguments (e.g. Pascal [1669] 1995; La Rochefoucauld [1678] 1981; Nietzsche [1878] 1994; Benjamin [1972] 1999; Bacon [1620] 1999). We are especially interested in a subclass of these epigrams that many have labeled "aphorisms." ${ }^{1}$ We argue in this article that the endurance of sociological slogans like Marx's concept of the "opiate of the masses" or Weber's "iron cage" of rationality are partly explained by their formal properties and that these formal properties indicate a modality of social thought that is too often ignored. Some sociological aphorisms have received thoughtful treatment, for example Garfinkel's (1996) discussion of one of Durkheim's key aphorisms, and Swedberg and Reich's (2010:27-8) analysis of Simmel's aphorisms. Yet the formal properties that drew Durkheim and Simmel (not to mention Pascal, Nietzsche, Bacon, Benjamin and many others) to write in the formal register of quite ancient wisdom traditions has not been thoroughly examined (though see Davis 1999). Nor has our discipline considered the impact aphorisms might have on the reception of a theorist's broader work and later intellectual currents.

This article unfolds in four sections. First, we explore the kind of intellectual work aphorisms accomplish, demonstrating that aphorisms are fundamentally ambivalent in sociological theory: they allow for powerful and transportable encapsulations of arguments, yet precisely because of their capacity for relative autonomy, these pithy sayings can lead to misreading and misrecognitions. However, it is these very misreadings and changes in focus that can drive productive new lines of inquiry. We then 
consider case studies of Marx's "opium of the peole," Weber's "iron cage," and two more recent sociological aphorisms. We end by considering what this means for sociologists today in a discussion section and brief conclusion.

\section{How Aphorisms Works}

The definition of an aphorism varies widely, but many scholars of the modern aphorism point to Francis Bacon's emphasis on aphoristic writing as a means of counteracting the orthodoxy of medieval scholarship (Stephenson 1980:3). For Bacon, the purpose of an aphorism was to get readers thinking on their own, absent a long string of arguments whose forward movement can distract from its potential errors. The impetus was not dissimilar from Plato's goals in situating his thought in dialogues, forcing readers to consider which speaker makes more sense. Much scholarly work on aphorisms returns to Francis Bacon's faith that aphorisms force an immediacy that can counteract earlier scholarly errors (Snider 2008, Stephens 1970).

While there is tremendous debate about what unites all aphorisms, Snider (2008:63), worries that too much of a focus on paradox (as seen in La Rochefoucauld) or on playfulness-as-an-end-in-itself (as seen in Barthes's analysis of La Rochefoucauld), can miss "something important: almost invariably, aphorists see their work as embodying positive truth in form, not merely a hermeneutic meditation on form, or a free play of signifiers." We focus here on this embodiment of a positive truth, and add to this a critical insight from Davis's theorizing about the role of the aphorism in sociological theory: it must be interesting, and it is that quality of interest that allows it to live outside its original context. His insights could be read as revealing another sociological aphorism, 
one we coin here: that there are only two kinds of arguments: the boring and the wrong. As Davis (1999:246) argues, “The interesting is more interesting than the true because Truth, as the final goal of knowledge, is static, whereas the Interesting, as the revelation of a potential understanding that propels the mind toward Truth, is dynamic."

But what makes aphorisms interesting? An important preliminary observation is that this must first be explained by reference to form, rather than content, since so many wisdom statements contradict one another in content, and since their formal characteristics have endured for so very long (Daniel et al 1987:482; Basgöz 1993). As Hayden White argues, any given form has a certain content, or at least provides a space through which certain content works in a way that it would not in another form. To the extent possible, we are concerned with this "content of the form" (White 1987). Our question, then, is what role does the aphorism's form play in the history of social thought? And further, how does aphoristic writing work in our discipline?

When Colonial American families read to each other from Poor Richard's Almanack (Franklin [1733-1758] 2004), Anabaptist Dissenters argued about sermons in English public houses, or French aristocrats mocked their fellow Salon members, they were often making sense of the world through the use of aphorisms, not through logical reasoning. Of course, the advent of social science has not meant the end of popular wisdom statements; nor indeed are social scientists free from the appeal of these nonrational devices. Aphorisms are often used to "stand in" for more complicated arguments. A pithy saying can therefore not only overpower a more intellectually compelling argument, it can also replace an argument, reducing its complicated steps to the parsimonious pieces of a formula. Herein lies the problem: an aphorism's very power can 
lead to the oversimplification of the argument from which it is drawn. Yet aphorisms are also immensely productive, both because of their relative transportability (Davis 1999:267-269) and their potential for creating new kinds of conversations and creative misreadings. Further, aphorisms can function in Bacon's sense of calling people to think with a freshness and immediacy not possible in other rhetorical forms. Along these lines, Simon Reader (2013:454) studies how Oscar Wilde's early aphorisms work as “a form of writing that treats pieces of information as actors rather than functional facts in methodological arguments." When aphorism become actors, their power becomes ambivalent: they can cross-pollinate but they can also misrepresent. Yet even that misrepresentation might be helpful. We call these mixed blessings "the ambivalence of the aphorism."

We explore three perspectives on the aphorism in the cases that follow. First, following Bacon, aphorisms can be understood as intellectual heuristics that generate interest and intensify focus, often to the effect of undermining confidence is accepted truths. From another, more critical perpsective, aphorisms can have precisely the opposite effect, crystallizing complex ideas into distortions of themselves that give rise to either strawmen that are easy to attack or indeed dogmas that are all too eagerly defended. A third perspective, explored throughout our discussion, threads between Baconian Enlightening and conceptual atrophy: sometimes, aphorisms give rise to productive misreadings.

As others have noted (Ermakoff 2017), even the most scientistic social science is rife with indeterminacy and communicative failures which often go unnoticed. We are therefore not arguing that aphorisms in sociology are utterly unique. Instead, in the 
tradition of reflexive sociology (Bourdieu and Wacquant 1992; Buroway 2003), we provide here an opportunity for sociologists to be thoughtful about how they use others' wisdom statements and how they develop their own. ${ }^{2}$

\section{Examples of Aphorisms}

What contemporary statements are aphorisms? $?^{3}$ At the pithy end of the spectrum, we might include “don't ask, don't tell”; "if you break it, you buy it;" and Senator Joseph McCarthy's "better dead than red". These share a quality of repetition (of a letter, word, or phrasing) that sets them apart from more prosaic articulations. Consider these alternatives: "don't ask about sexuality or talk about it"; "if you break anything, you must pay for it;" and "better to die than be a communist". The repetition of the originals is pleasing to the ear and makes the statement more likely to be repeated and remembered; in effect, they are more interesting (Davis 1999).

Slightly less mellifluous contemporary wisdom statements might include: "it takes a village to raise a child" and "there are no atheists in foxholes". These are phrases without any conspicuous rhythmic or sonic characteristics to set them apart, yet they include odd turns of phrases and evocative symbols that make them more memorable. "It takes many people to raise a child" might be viewed as an obvious and uninteresting truth. By saying "village" in place of "many people," the speaker triggers images of community and belonging that hint at something more profound than merely "many people." Yet the two statements make essentially the same claim. Similarly, "there are no atheists in foxholes" is likely to be viewed as a more elevated and resonant statement than "there are no atheists in moments of great stress." Neither is literally true, yet the 
former seems more profound to the degree that it taps into our shared notions of the horror endured by soldiers in foxholes. Each of these differences ties into Davis's helpful distinction between the boring and the interesting in his study of the aphorism: as we suggest here, echoing Davis, the form is actually more important than the content in making something compelling rather than cliched (1999).

Our examples are not intended to sketch hard and fast categories of aphorisms. Rather, we introduce this variety of utterances to convey the sense of the tools that authors can and do draw upon to grant their statements a sort of cultural power that elevates them from the mundane and imparts some relative separability and with that separability, as Reader describes it, a kind of agency. In this sense, our understanding of the aphorism is not quite the same as that laid out by Davis. "The thoughtful aphorist," to use Davis's arresting image, might have intended to "[take] the reader's notes" (1999:253), yet the simplicity and arresting form of such encapsulations make them much more powerful than summaries. ${ }^{4}$ An aphorism's formal qualities make it more attractive to engage as a thing in itself, thereby also making it more vulnerable, and more powerful—and interesting.

\section{The Ambivalence of Aphorisms}

From Bacon to Murray, the power of aphorisms to challenge and provoke has long been attested. A second, more critical perspective on the power of the aphorism stresses the way these utterances subtly form our thinking. Most troublingly for social scientists concerned with leading their readers toward truth and reason, the apparent truth 
of an aphorism is often intimately connected, not to the authority of the speaker, nor to the individual who first composed it, but rather to its ability to perform its truth.

The "trap" of the aphorism is its very interestingness and the self-fulfilling nature of its arresting qualities. And this danger has long been recognized by the masters of traditional wisdom literature. For example, the author of the Book of Proverbs develops a conceit around the image of personified "Wisdom" and "Folly." Wisdom encourages those passing by to "eat of my bread, and drink of the wine which I have mingled" (9:5). Folly entices the simpleminded with the anti-social aphorism, "stolen waters are sweet, and bread eaten in secret is pleasant" (9:17). While Wisdom speaks in unadorned and honest terms, Folly's language, sensuous and aphoristic, is itself enticing (Perry, 1993:56). The source of wisdom in general is explicitly defined as "the fear of the Lord" (9:10), while the contrast between the two reveals folly to emerge from the selfinterestedness that leads to conceit and the refusal to learn through communication.

Ironically, this is the exact opposite of Bacon's intended use of the aphorism, which is to free readers from the shackles of authoritative knowledge. And while it seems fair to argue that aphoristic writing can drive readers either into arguments-by-authority or into a creative reckoning with what they read, the most important piece that we take from both readings of aphorisms' purpose is their relative separability and with that separability, a form of agency. That agency makes the fundamental ambivalence of aphorisms all the more powerful: they can function as autonomous authorities or they can compel further thought.

Here we arrive at the third perspective on aphorisms that we mentioned above. The relative agency of aphorisms can be understood in a slightly different way through 
Harold Bloom's study of "misreading." In The Anxiety of Influence (1973) and A Map of Misreading (1975), Bloom draws on Nietzsche and Freud to describe how great poets deal with the anxiety of earlier poets' talents by creatively "misreading" their mentors' work "so as to clear imaginative space for themselves" (1973:5).In a Bloomian sense, when a pithy expression is itself not only the subject of debate but actually the agent to which actors respond, then the various potential caveats that could temper that aphorism are no longer relevant: they are uninteresting. This emphasis on unpacking what is interesting might well lead to a more "fractal" and cyclical understanding of social science than the more orthodox teleological and positivist framings (Abbott 2001:3-33), but whether sociology is actually a positivist science moving ever closer to the Truth is itself a subject of much debate (Eckberg and Hill 1979; Steinmetz 2004), even if Abbott would argue the differences are more fractal than absolute (2001). Nonetheless, what is important for our argument here is that aphorisms' arresting formal qualities and relative separability can make them both fertile grounds for reinterpretation and also make their original arguments vulnerable to misreading, yet that very misreading is precisely the source of some of the greatest fertility.

\section{Sociology and Aphorisms}

Alongside Bacon's Novum Organum, the first publication of the Maximes of

François de la Rochefoucauld is often cited as the entry-point of the modern aphorism. ${ }^{5}$ The Maximes are a series of aphorisms detailing various forms of human behaviour and characterised by its distinctly misanthropic tone. ${ }^{6}$ La Rochefoucauld's significance for the present argument rests in the way he establishes the authority of his insights into 
human nature (in essence, an early form of sociological analysis). For La Rochefoucauld and the salon circles of the mid-seventeenth-century, the aphorism's unique power lay in its ability to deflate anyone pretending to those most ephemeral and subjective of virtues, tastefulness and propriety. La Rochefoucauld's authority, accordingly, rests on two things: first, his insight being interpreted as a sociological faculty informed by his status as a participant-observer; and second, the ungrounded belief that his taste and values are coextensive with the social milieu he describes, making him wise in the ways of contemporary fashions. Yet there is an additional, formal authority beyond that of $\mathrm{La}$ Rochefoucauld, one described in Barthes's ([1981] 2009) study, and, additionally, in examinations of the aphorisms of Francis Bacon and Oscar Wilde (Reader 2013), among others: aphorisms are bon mots, well-placed words that work and carry on their own.

In what follows, we will consider famous aphorisms by Marx and Weber as well as, more briefly, two more recent sociological aphorisms. In each case, we argue that these aphorisms provide their progenitors with greater authority through the attractiveness, separability, and relative agency of the form while also potentially weakening their rhetorical positions, given that their arguments can then be proven or disproven by simply engaging with the wisdom statement itself. However, these aphorisms each also provide for an important point of leverage for creative misreading, allowing theory to move forward precisely because of the power of the aphorism.

It is worthwhile, briefly, to examine our methodological choices here. Our intention, in providing these examples of misreading and adaptation is not to provide a systematic study of how aphorisms have been used and adapted in sociology, a study we would encourage but for which we have insufficient space here. We identified four 
prominent sociological aphorisms - two classical and two modern — and we used various academic search engines, especially Google scholar and JSTOR, to check how often and when these aphorisms were engaged. Our study here is not intended as a systemic study of how and when sociological aphorisms are coined, adapted, and used, but rather a theoretical argument about a set of sociological and rhetorical processes. Similarly, we recognize that Google Ngram is a deeply imperfect method for gauging the relative popularity of a phrase (Pechenick, Danforth, and Dodds 2015). We intend these Ngram views as we intend our qualitative dips into the use of aphorisms in sociological theory: as illustrations of sociological processes that can later be checked using more robust quantitative methods. We believe the processes we identify here are broadly representative, but we leave it to other scholarship—including some we are working on ourselves - to provide more systemic analysis of adaptation and usage.

\section{Karl Marx's "opium of the people" / "opium des volkes"}

\section{Marx on Religion}

Marx was famous for many important aphorisms, including "Workers of the World Unite!" (Proletarier aller Länder, vereinigt euch!) and "all that is solid melts into air" ("Alles Ständische und Stehende verdampft"), both from the Communist Manifesto ([1888] 1978f). Yet, within sociology, Marx is perhaps most famous for his declaration of religion as the "opium of the people" in his "Critique of Hegel's Philosophy of Right" ([1843] 1978b). Of course, Marx declared religion to be a lot of things:

Religion is the general theory of this world, its encyclopedic compendium, its logic in popular form, its spiritual point d'honneur, its enthusiasm, its moral 
sanction, its solemn complement, its general basis of consolation and justification. It is the fantastic realization of the human being inasmuch as the human being possesses no true reality. ([1843] 1978b:54-55)

Not much later is his famous critique of religion, that "sigh of the oppressed creature, ... sentiment of a heartless world,...soul of soulless conditions" and, of course, "opium of the people" ([1843] 1978b:54). Religion is an "illusory sun about which man revolves so long as he does not revolve about himself" ([1843] 1978b:54), an error soon to be corrected by history itself.

But what is the source of these illusions? Why would people have a religion at all? A benefit of aphorisms is that their pithiness can make for easy transportability and a kind of agency relatively separate from the original text, which has certainly been the case with the wide-ranging use of Marx's phrasing. Yet, within its context, Marx's phrase is not as transportable as it might appear.

If we only have the phrase, "opium of the people," it might seem obvious that religion is primarily a means of preventing revolution, a creation of cynical capitalists who encourage the poor's reward in the next world to reap their own in this one. Yet can Marx's paean to "moral sanction [and] fantastic realization" be so easily dismissed? His praise of religion echoes the remarkable compliments he provides the bourgeoisie in The Communist Manifesto, which are often about religious artifacts like pyramids and cathedrals ([1888 1978f:476; see also Berman, 1987). Of course, there is more than one Marx, and this plurality of voice is nowhere more obvious than in his descriptions of religion. Observe, for example, the contrast between Marx's tolerance of religious tolerance in On the Jewish Question ([1843] 1978a:32, 41) and his much later unapologetic contempt for "religious freedom of conscience" in Critique of the Gotha 
Program ([1875] 1978e: 540). For Marx, religion is the apex of early human intellectual creation: the fact that it is an illusion does not negate its creative power.

And neither its historical importance. As one element of consciousness, religion is a central element in the third of Marx's four stages of history ([1845-1846] 1978d:156159). Indeed, consciousness of nature forms a "natural religion" that "is determined by the form of society and vice versa" ([1845-1846] 1978d:158). This natural religion is formed, at first, by humanity's "consciousness of nature, which first appears to men as completely alien, an all-powerful and unassailable force, with which men's relations are purely animal and by which they are overawed like beasts" ([1845-1846] 1978d:158). Whatever natural religion's referent actually is, Marx seems just as comfortable using terms like herd or tribal consciousness (Guhin 2014).

The effort to control the natural world is now the province of industry, and Marx appears to discredit any normative commitment to a certain human relation to the natural world. After all, if it is social conditions and not ideas that drive revolutions, then why should one idea of relating to the natural world be any more correct than another? The answer is simple enough, even if the late Marx did not want to be troubled by the normative bother of it: humans ought to relate to nature through spontaneous creation ([1844] 1978c:75). This anthropological claim provides a useful prism though which to view Marx's comparison to religion in the same section. Marx is concerned, quite explicitly, with how both religion and modern capitalism rob workers of their own consciousness: "it belongs to another; it is the loss of...self" ([1844] 1978c:74). As Guhin (2014: 583) puts it, "Under natural religion humans are nothing but a herd; under modern 
capitalism humans are nothing but animals." Just as the proletariat needed the bourgeoisie to conquer, so the self needed a religion to supersede.

\section{On the Use of Marx's Aphorism}

While those who use opium might do so for complicated reasons, and while the drug might well produce certain kinds of creativity, the analogy that religion is to people what opium is to opium-users simply cannot contain the complexity of Marx's many nuanced positions on religion. Yet there is also something incredibly effective about the phrasing and its imagery, particularly within the political and economic context that Marx intended it: as various scholars of religion have shown, religion can, in fact, lead to quietism - even if it can also lead to revolution (for overviews, see Appleby 2000 and Norris and Inglehart 2004). It seems easy enough both to translate the phrase to other possible opiates of the people and to think that, through disagreeing with the phrase itself, one can disprove Marx on religion. McKinnon challenges such readings by showing how the complicated, multivalent nature of opium in Marx's era helps to make Marx's metaphor dialectical rather than indexical: "the 'traditional' readings of religion as 'opium of the people' ... neglects the context and dialectical movement, in which opium, as a condensed signifier, brings together both expression and protest in one moment" (2005:25). Yet we are arguing something subtly different here: the problem is not only that readers lack a historical context to understand Marx's aphorism; the problem is at least partially that the very form of the aphorism can encourage an argument's too simplistic encapsulation. 
Because of the ease with which "opium des volkes" can be translated, there have been four dominant translations, each a different mixture of opium/opiate and masses/people for the phrase's two nouns. As an Ngram here indicates, their relative popularity was at their highest between the 1930's and 1970's as the Cold War peaked.

$<<$ Figure 1 about here $>>$

$<<$ Figure 2 about here $>>$

Another Ngram found that the phrases "another opium of the people" and "new opium of the people" were common articulations, with various alternative "opiates", including radio, television, media more generally, tourism, capitalism, images, sports, consumerism, nationalism, family, and a host of other possibilities becoming religion's replacement. While these other elements of life might well provide the same sort of respite from life's cruelty that opium could provide, it is not clear that they are able to substitute for religion in the way that Marx describes it. While we do not have the space to engage all the uses of these phrases - which, a quick Google scholar search will reveal, continue to the present - we will examine one of them to show how the form of the aphorism has allowed a relative separation from Marx's larger argument.

As one quick example, consider Sherry Turkle's pathbreaking book on computer users in the 1990's, Life on the Screen. In it, she cites a concern she had even earlier, quoting a piece she had written in the 70's: "It would certainly be inappropriate to rejoice at the holistic and humanistic relationship that personal computers offer if it turns out 
that, when widespread, they replace religion as an opiate of the masses" (1995:244). Note that no context is given to the maxim — not even a reference to Marx himself. This is both the strength and the weakness of the aphorism: it is easily transportable and seemingly self-evidently true. Yet to argue that computers could function in the same way as Marx's conception of religion is an ambivalent rhetorical move: it is a compelling and provocative transposition of a powerful image, yet it also at least potentially misunderstands the function and role of both religion and opium in Marx's broader argument about social change.

The use of this pithy phrase was effective for specifically sociological work as well, although, within the top sociology journals (American Sociological Review and American Journal of Sociology), the phrase was used less as a replacement for other supposed opiates than as a means of critiquing Marx's argument, with the authors often believing that showing how religion was not necessarily an opiate was sufficient to prove Marx wrong (Billings 1990; Heirich 1977; Hoult 1950). For example, perhaps because of the necessary challenges of simplifying the many moving parts of Marx's argument for large quantitative studies, certain well-published statistical analyses have tended to use Marx's maxim as a short hand for religion's relationship to class consciousness. In their 1963 study of "correlates of class consciousness among textile workers," Manis and Meltzer exemplify exactly this sort of simplification, describing how "various historical events combined with Marxist ideology to provide a perception of religion ('the opiate of the masses') as an ideological force operating to minimize class consciousness and class conflict" (1963:180). They then use reported frequency of church attendance as a potentially important correlate to explain class consciousness, which is potentially even 
more problematic as an engagement with Marx's argument, given that church attendance references a particular practice while Marx's work on religion—even his famous metaphor - is much more centered on a phenomenological orientation to the world. Similarly, Stark's contemporaneous quantitative study of “class, radicalism, and religious involvement" (1964) is a more nuanced study of how religion competes with and interacts with political radicalism, yet his engagement with Marx (1964:699) is ultimately similar, rooting much of his interpretation in one simple question: does religion keep people from political action or not?

In both cases-whether using the phrase "opium of the people" as a catch-all to describe anything that mollifies the masses, or as a means of representing Marx's larger argument — the aphorism's simultaneous power and weakness are in view. "Opium of the people" gives Marx's larger argument about religion an impressive pithiness with arresting imagery and apparently universal translatability, yet it also renders the argument simple and therefore easier to attack.

However, there have also been important developments of Marx's work precisely because of this "misreading." Acknowledging the complicated nature of religion in Marx's though is perhaps more academically honest; however, thinking of religion as primarily an opiate allows for a straightforward and bright-colored heuristic, a way to think with or against the aphorism towards other kinds of work. For example, much of the theology of liberation literature, even if quite well-versed in Marxist theory, has focused on the opiate aphorism as a synecdoche for Marxism writ-large, a misreading in the Bloomian sense, but also a means through which a different kind of activist theology can develop in explicit contrast to a soporific faith (Candeleria 1990). The aphorism 
might encourage a misreading, but such a misreading is not always a problem. Indeed, it can be productive.

\section{Weber's "Iron Cage" / "stahlhartes Gehäuse"}

\section{Weber and Prophecy}

Some readers may be unsurprised to find that Marx integrated aphorisms into his work, especially given his famed skills as a journalist and polemicist. It is more surprising to see the same impulse emerge in the work of Max Weber, a scholar famously wary of charismatic leadership. ${ }^{7}$ Nevertheless, we see in his writing the occasional use of aphorisms, and nowhere more evidently than in the concluding chapter of The Protestant Ethic and the Spirit of Capitalism. ${ }^{8}$ Although there are multiple instances of wisdomwriting in that chapter, ironically, for American sociologists, it was not Weber but rather his early translator, Talcott Parsons, who crafted his most enduring saying. According to Parsons's translation, Weber writes: “In Baxter's view the care for external goods should only lie on the shoulder of the 'saint like a light cloak that can be thrown aside at any moment.' But fate decreed that the cloak should become an iron cage" (1992:125). The last chapter concerns the breaking apart of the links tying one's calling with one's worldly acquisition or ascetic practices. Near the beginning of the chapter, Weber quotes Benjamin Franklin's famous aphorism, "time is money," disagreeing that this is always the case but affirming that "the proposition is true in a certain spiritual sense" (1992:104) for the individuals Weber is discussing. 
It is worth pausing here to acknowledge that this potential misreading of Franklin's aphorism is exactly the kind of productive, creative misreading we have been describing. Franklin himself was not nearly the kind of earnest money-grubber Weber and others describe: thinking, after his retirement, more "like a genteel aristocrat, not a tradesman" (Wood 2005:9). Yet Weber takes Franklin's aphorism as emblematic not only of Franklin himself, but also of a new economic order. That misreading led to one of the classic books of sociology: a productive misreading if ever there was one.

In his final chapter, on page 122, Weber switches tones, moving from analyst to "prophet." He enters this prophetic mode by summarizing his argument thus far. We quote Parsons' translation of this passage at length to demonstrate the place Franklin's aphorism plays at this pivotal moment of the text:

One of the fundamental elements of the spirit of modern capitalism, and not only of that but of all modern culture: rational conduct on the basis of the idea of the calling, was born - that is what this discussion has sought to demonstrate- from the spirit of Christian asceticism. One only has to re-read the passage from Franklin, quoted at the beginning of this essay, in order to see that the essential elements of the attitude which was there called the spirit of capitalism are the same as what we have just shown to the content of the Puritan worldly asceticism, only without the religious basis, which by Franklin's time had died away. (Weber 1992:122-3)

Just as the Franklin aphorism serves as an entryway to the deep structures of capitalist thought, so too it is now revealed to serve as a link from capitalism to the Protestant ethic. This revelation is seized by Weber as the opportunity to consider the meaning of an acquisitive ethic for his own age. His language becomes more emphatic, noting, "The Puritan wanted to work in a calling; we are forced to do so" (1992:123). There is no evidence presented that Weber or his reader are "forced" to work in a "calling." The concepts flow together through the power of the aphorism itself, which is used to stand in 
for a whole line of reasoning. Drawing on the image of the Puritan and this sorry state of indentured servitude, Weber describes the "tremendous cosmos" and "irresistible force" of the modern capitalist order, one that he warns may endure "until the last ton of fossilized coal is burnt" (1992:123). And it is at this point that Weber (according to Parsons) writes of "an iron cage" (1992:123). But let us move on before returning to consider this peculiar phrase.

In the two pages that remain, Weber writes in a consistently elevated and poetic tone. He describes "the rosy blush of [capitalism's] laughing heir, the Enlightenment" (1992:124), returns twice to the concept of the "cage," and then transitions into his most prophetic statement, a prediction of three possible futures. One future would include the rise of new prophets, which would in turn generate new orders of meanings that would look different to us but would grant a similar degree of psychological stability as enjoyed by our Puritan ancestors. A second possible future would simply be a return to the old, discarded Puritan order. The third future would be something very alien indeed, which Weber describes as "mechanisierte Versteinerung," or "mechanized petrification" (in all translations). And to define this third, nightmarish scenario, Weber includes a very traditional sort of wisdom statement: "Fachmenschen ohne Geist, Genußmenschen ohne Herz" (1992:124).

Note first the formal traits, which can be detected even without translation. The two phrases repeat the form "X-menschen ohne Y"; and the two end nouns, Geist (spirit) and Herz (heart) share a rhythm. Parsons translates this as "specialists without spirit, sensualists without heart”. The third prophesied future thereby poetically suggests some broader societal malaise which remains unstated. From this elevated perch, Weber walks 
his reader back down to earth: "But this brings us to the world of judgments of value and of faith, with which this purely historical discussion need not be burdened. The next task would be rather to show the significance of ascetic rationalism..." (1992:124). In this way, the aura of scientism is reasserted over the text, and the prophetic moment is said to have passed, even as its dramatic power lingers, coloring the reader's experience of everything that preceded it.

\section{On the Use of Weber's Aphorism}

Ironically, despite Weber's own disavowal of this "world of judgments of value and of faith", it is precisely this short section that has captured the imagination of so many of his readers and informed important aspects of his sociological reputation. To that end, we will briefly move backward in his text to consider the fate of the pivotal image of the "iron cage."

Parsons's translation of Weber has been interrogated by several commentators (see especially Baehr 2001). What seems beyond dispute today is that his translation of the key phrase, "stahlhartes Gehäuse," is very loose, and yet the concept of the "iron cage" is repeatedly associated with Weber. To get a sense of the popularity of the term, we include here comparison Google Ngram of "iron cage" and "bureaucratic rationality," the latter being a more literal and more accurate description of Weber's ideas. We find Parsons's formulation barely registered in the database for its first two decades (19301950), picking up a bit through the 1950s to 1970 , and then taking off, with a steady rise through the 1970s and 1980s to level off at the beginning of the 1990s, declining in the 
2000s. At no point was the more descriptive term "bureaucratic rationality" cited more frequently than "iron cage".

$<<$ Figure 3 about here $>>$

A richer source of information is the use of the two terms in the American Journal of Sociology (the only American journal that has been consistently ranked at the top of the field for the entire period in question). Only six articles used the term "bureaucratic rationality," while 91 articles included the term "iron cage." The first work that included the term in its title, Mitzman's ([1969] 2002) The Iron Cage: An Historical Interpretation of Max Weber, was published at about the time that the Ngram begins to show increased references being made to the term. Similarly, DiMaggio and Powell's "The Iron Cage Revisited: Institutional Isomorphism and Collective Rationality in Organizational Fields" (1983), the fourth article in our sample to cite the term, likely inspired the naming of several of the other articles. The spike of interest in 1998 followed the publication of two articles by the same authors that used the title (Feldmann and Kelsay 1996; Feldmann and Kelsay 1997). Finally, the decline of interest throughout the 2000s may be associated with Baehr's (2001) forceful intervention and the two translations that followed, one by Baehr and Wells (Weber 2002), who prefer the term "shell as hard as steel," and the other by Kalberg (Weber [2001] 2012), who substitutes "steel-hard casing" for "iron cage". Regardless of the specific numbers and pathways of influence, our point here is quite simple. Despite only occupying three pages of a 125-page document, and despite Weber's own dismissal of this section in the text itself, these pages of The Protestant 
Ethic have had enduring resonance for his audience and profound impact on his sociological reputation. The quotation within which "iron cage" appears is both ungainly in form and not attributable directly to Weber, yet this image has haunted the discipline. The poetic Weber, the prophetic Weber, is indexed through this turn of phrase, and from this we gain access to the other aphorisms and sayings in this section. It is our argument, then, that Weber wrote the concluding pages of The Protestant Ethic to serve as both a conventional conclusion, summarizing the key argument of the book, but also as a means of helping to counter the very phenomenon he describes. He counters the loss of prophets by writing prophetically.

For sociologists writing after Baehr's correction, the term "iron cage" has a strange indeterminacy. On one hand, there appears to be a general recognition that using it as a straightforward translation is inaccurate, and yet the power of Parsons's particular translation remains. For example, when Ahram and King (2012:171) question why Weber rather oddly viewed the term war lord as an analytical rather than normative category, they conclude that it is because Weber was "dubious of the virtues of the "iron cage' imposed by acceptance of the seemingly rational and impartial state apparatus". The quotation marks around the term seem to suggest that the authors are aware that the term is contested and yet still prefer to use it - presumably because they prefer its resonance. Foster and Holleman (2012:1660), writing about Weber's views on the environment, similarly hedged when they used the term, writing "some commentators ... have recognized that it [disenchantment] is also connected to his references, at the end of The Protestant Ethic, to an iron cage (steel casing)". 
In its most extreme form, Weber's "iron cage" has become a standalone symbol of global capitalism. This development has been aided by the extraordinary influence of DiMaggio and Powell's (1983) article, which describes the sorts of isomorphism in organizational forms which are associated with globalization. Hence Sallaz (2012:101) titles one quadrant of a two-by-two table "The Iron Cage" to describe instrumental mechanisms that have convergent outcomes in organizational forms.

Indeed, DiMaggio and Powell's 1983 article merits special attention here in that their focus on revisiting the iron cage accomplishes much the same intellectual work we earlier described for liberation theologians' engagement with the "opium of the people." Their focus on one particular aspect of Weber's argument - the "haunting" "imagery of the iron cage" (1983:147)—parallels Weber's focus on Franklin's aphorism, even if, like a liberation theologian's engagement with the "opiate of the masses," this focus is not because they lack knowledge of the aphorism's context. It is instead as much a creative refocus as a creative misreading. The aphorism, taken as relatively separable from the rest of the text (because of its memorable qualities) can function as a prism through which to refract other theories, including those theories that build on "trends to which he [Weber] called attention" (1983:158). Indeed, the concept of isomorphism-in addition to its alliterative relationship to "iron cage"-has a nice conceptual connection as well, with the hardness of iron and the fixity of a cage helping to capture the durability and strength of isomorphic processes within organization, a process perhaps not as well described in later translations of Weber's phrase. The creative application of the iron cage aphorism not only helps DiMaggio and Powell; it at least potentially makes us read Weber through DiMaggio and Powell. 
As with liberation theologians' knowledge of Marxism, it is not that DiMaggio and Powell's knowledge of Weber is lacking. Rather, they use a certain aphorism to stand in for a broader argument, thereby providing a more circumscribed, and thereby potentially more productive, view of the social world. Just as "rational choice" theorists do not actually believe that that all people are rational but rather use that model as a heuristic through which to develop theories about social life, so certain scholars can use aphorisms as a way to simplify and thereby better theorize the social world. Even Weber's potential lack of knowledge about Franklin is not necessarily a problem in terms of knowledge production, as a certain positivist critique might claim. The question is not what Weber got wrong about Franklin because of the aphorism but rather whether his potential (mis)reading of the aphorism led to a productive intellectual contribution with important and justifiable claims about the world.

\section{On Modern Sociological Aphorisms}

In a recent book chapter, Philip S. Gorski has critically engaged with a more recent sociological aphorism, Charles Tilly's "war makes the state, and the state makes war" (Gorski 2011:1). This phrase, often called the Tilly thesis, seems to have appeared first in Tilly's mid-career work The Formation of National States in Western Europe (1975:42) as "War made the state, and the state made war." There, it referred to the mutual development of the Western European state's coercive and extractive capacities. It was amended by Tilly ten years later to take on the present tense, where it was also shorted to simply "Wars make states" (1985:170). By the time Tilly wrote Coercion, 
Capital and European States, it was well-know enough that Tilly would title a chapter simply "How Wars Made States, and Vice Versa" (1992:68-95).

As with Marx's "opium of the people" and Weber's "iron cage," the Tilly thesis has been enthusiastically taken up by scholars as a point of discussion and citation, with hundreds of references to the variations of the term showing up in searches of scholarly material. ${ }^{9}$ At least three scholarly pieces have adopted Tilly's phrase in their titles (e.g. Cohen 1984; Kroenig and Stowsky 2006; Morgan and Reiter 2013). In short, the aphorism is as close to a sociological success story as we encounter. And yet, as Gorski argues, the concept was not original to Tilly, and Tilly's revision, "a lightly modified, second-order derivative" (Gorksi 2011:2), did not resolve many of the challenges that had undermined those earlier articulations.

Nonetheless, the aphorism has been immensely productive, not least because of this ambiguity: in this sense, Tilly's aphorism could be said to functions in the Baconian sense, a relatively detachable quotation that forces people to consider particular empirical and theoretical questions, focusing the conversation in a particular way without compelling any hard orthodoxy. Of course, these conversations are not always positive. Orthodoxy about an aphorism can take shape in ways authors and groups of experts would rather they do not: for example, Bortolini has shown how Bellah's use of Rosseau's evocative paradox, "civil religion," has taken on a life that Bellah did not at all intend for it (2012).

Similarly, a recent article in Sociological Methods and Research (Jerolmack and Khan 2014) uses the provocative aphorism that "talk is cheap" in its title and as a central conceit throughout the article to downplay the importance of the interview methodology 
and to emphasize the importance of ethnographic study of in-situ interaction. The article received an incredibly wide response, prompting a set of responses in the journal itself and many follow-up articles, blog posts, and conference panels. Many of the responses defended the value of talk, emphasizing the various ways interview methods are not, in fact, cheap. Yet, a careful reading of both the article itself and the separate publications of both Jerolmack and Khan will show that they do not really think talk is cheap either: both take advantage of interviewing respondents, and not all of the interviewees are totally entrenched in their field sites (Jerolmack 2013, Khan 2010). Some could read this as bad faith — which we do not believe it is, not least because Jerolmack and Khan are primarily critiquing a specific kind of interview methodology which, to our knowledge, neither practices. Instead, the aphorism "talk is cheap" functions as a kind of creative misreading of interviews in general, one that people are then forced to take on its own terms, in the Baconian sense. A more straightforward claim—that interviews can be good, but you have to be careful with them-would be more accurate but less interesting, and probably also less productive. If all arguments are either boring or wrong, then "talk is cheap" is wrong, but it is wrong in interesting and productive ways.

\section{Discussion}

Few sociologists would hold that our discipline is strictly rational, and our proximity to literature have been well-documented (e.g. Coser, 1972). Lepenies (1988) and Zald (1991) both make the stronger case that sociology is partly (but profoundly) humanistic in its distinctive content and forms, while Abbott (2001:6) describes the discipline as "irremediably interstitial," spilling over into the scientific and humanistic 
realms in equal degree. We add to these discussions by describing the way that the literary qualities of aphorisms can both distort and potentially move forward intellectual history, in both scientific and literary senses. When Weber reads a Franklin aphorism a certain way, or DiMaggio and Powell read a Weber aphorism another way, they are both moving intellectual life forward and also, in some sense, doing a kind of interpretive violence to it: in the first case, by claiming Franklin's maxim is actually representative of America, and in the second case, by using what is potentially a bad translation to reread Weber through the concept of institutional isomorphism. But as much as these might be misreadings, they are also, to use Bloom's term, creative, not only in the sense of cleverness, but in the sense of creating something. These misreadings help us to focus our intellectual energies in different ways, powered by aphorisms, that, in Bacon's sense, make us think about the world in innovative and exciting ways.

To conceptualize social theory as driven by "seeing differently" might rub some positivists the wrong way, especially those who would prefer what Abbot calls a more "Hegelian model" (2001:15). Yet, following Abbot's model of interstitial social science, it actually makes sense that aphorisms are ambivalent, capable of both fertility and debility (2001:55). On one hand, they can be seen to strengthen and aptly summarize an analytically rigorous and value-neutral argument. Yet, precisely because of their power, they can also be taken apart from the argument itself, made to do work that might be productive and might not. The aphorism might compel a certain kind of careful reflection, a la Bacon, but it also might function as an attractive argument by authority, accomplishing exactly the opposite of what Bacon intends. 
Rather than ask whether or not people should use aphorisms, a more interesting question might be simply to reflect on what happens when they do. Most of us want our research to interest our readers, and the judicious use of aphorisms offers authors a highly effective means of focusing long and complex arguments. We might compare this to the drive for sound bites and talking points that has followed alongside global mediatization processes (e.g. Hjarvard 2008). The value in distinguishing one's work in a crowded marketplace can hardly be ignored, and it behooves authors to draw on a variety of formal devices to make their research connect with their audience.

Unlike a standard soundbite, however, sociological aphorisms can trigger very positive forms of intellectual engagement and discussion which can in turn result in a much richer conversation. Here we may recall the arguments Abbott (2001:10-15) has advanced concerning the fractal character of sociological distinctions generally. From this perspective, the use and misuse of aphorisms allows entrepreneurial authors to scale up or down from the original subject matter to create powerful new insights into social life given additional potency by virtue of their unexpected sycresis (Abbott 2001:43). Nonetheless, aphorisms can sometimes also lose something important about their context, especially when they are removed entirely from the arguments from which they are drawn (Braddon-Mitchell 2001). Such loss is itself ambivalent: it can, à la Bacon, compel people to think on their own with and through the aphorism. But aphorisms can also efface this loss, appearing complete, and indeed authoritative. In this sense, aphorisms are prone to the problems of indeterminacy, severing what Ermakoff (2017:135) describes as the connection between concepts and claims. Aphorisms might well function within the ultimate "unnoticed" setup, engendering "merry-go-round types 
of critical exchanges" (Ermakoff, 2017:135) rather than advancing our knowledge of social life. Yet we would suggest that such cynicism is not merited, at least not as a global claim. As we hope to have shown here, aphorisms can often be quite productive, precisely because of their separability from their original contexts and the creative misreadings they engender.

\section{Conclusion}

Aphorisms are elements in the sociological repertoire, and they-along with other rhetorical devices - might serve as a valuable point-of-entry to the study of rhetoric within sociology. While it is certainly the case that good arguments are not only effective because of rhetoric, rhetorical work is much more important than a certain scientific selfimage some sociologists might hold. For that matter, rhetoric is more important to the work of "hard" scientists than they might want to admit. Indeed, studies of scientific expression could be especially instructive for future studies of rhetorical form in sociological theory, helping to show how various sciences—social, biological, and physical — produce knowledge that is "not special but social; the result not of revelation, but of persuasion" (Gross 1990:20). Again, Bacon is a paradoxical figure here, in that his aphorisms are meant at once to persuade and to persuade against easy persuasion, encouraging people to think on their own (Gaukroger 2001).

To the degree that science is communicated linguistically between people, then of course it is necessarily a rhetorical enterprise, and also a social, political, and sociological one. Yet, acknowledging all of this, Kitcher nonetheless warns that rhetoric's focus on the "surface may distort a scientist's vision of the depths" (1995:48). 
Rather than make so grand a point about how sociologists ought to talk, we instead suggest that sociologists take note of how we talk, especially our use of the aphorism. These memorable phrases can aptly summarize or give new insight into a social process. They can beget a creative misreading of earlier work, developing a new discussion or effacing earlier arguments or, sometimes, both at once.

Furthering the aims of a reflexive sociology, we have built on Davis (1999) to identify and describe the aphorism in the sociological tradition. In doing so, we have noted the role aphorisms play in the reception, interpretation and creative misreading of social theory. We have traced two important aphorisms ("opium of the people" and "iron cage") in some detail and coupled those studies with shorter descriptions of two more contemporary aphorisms ("war makes states and states make war" and "talk is cheap"). We have looked at these four aphorisms from three perspectives: first, from a Baconian perspective that highlights the power of aphorisms as a stage for positive truths; second, from a critical perspective that highlights the coercive and distorting effect of aphorisms; and finally from a Blooming perspective that emphasizes the creative and transformative aspects of the form. This theoretical project may provide a pathway for subsequent empirical investigations, and we would encourage future studies that take advantage of various big data methodologies, as well as projects more similar to the present article that could trace other key sociological aphorisms. We also hope this article helps to encourage a broader commitment to a study of the rhetoric of sociology within sociology. Many questions remain. For example, do other aesthetic and rhetorical choices by social thinkers have equivalent effects? 
Taking notice of aphorisms could also help us to focus on what we —or those we read - are using aphorisms to do. Is this about obfuscating a lack of data or creativity with a catchy phrase? Or is an aphorism actually a new way to think about the world, all the more alluring because of something in its form, whether a powerful image, a clever turn of phrase, or an unexpected analogy? Two or three lines of good writing should not be allowed to stand for judgements better rendered as entire arguments. A sentence should not be a savior. Even if it often is.

Yet even if a sentence should not be a savior, it is often quite helpful for a sentence to be a stopper, to arrest us, in Bacon's sense, and make us think differently about the world or ourselves or the relationship between the two. Take our own aphorism, which we have been repeating throughout this text, that there are only two kinds of arguments, the boring and the wrong. Of course, this is not true: there are many arguments that are both boring and wrong or that are neither. But the pithy phrasing might force us to examine whether this claim is really true, and how. The best sociological aphorisms have this kind of agency, often with a relative separability from their original contexts. An aphorism might be wrong, but it is by definition never boring. And working out why it is wrong might well lead to something right. There is not much more you can want from words. 
On the Ambivalence of the Aphorism in Sociological Theory

Thomas Crosbie, Royal Danish Defence College and Jeffrey Guhin, UCLA

\section{Figures}

Figure 1: Google Ngram of "opium of the people," "opium of the masses," "opiate of the people" and "opiate of the masses," 1900-2010.

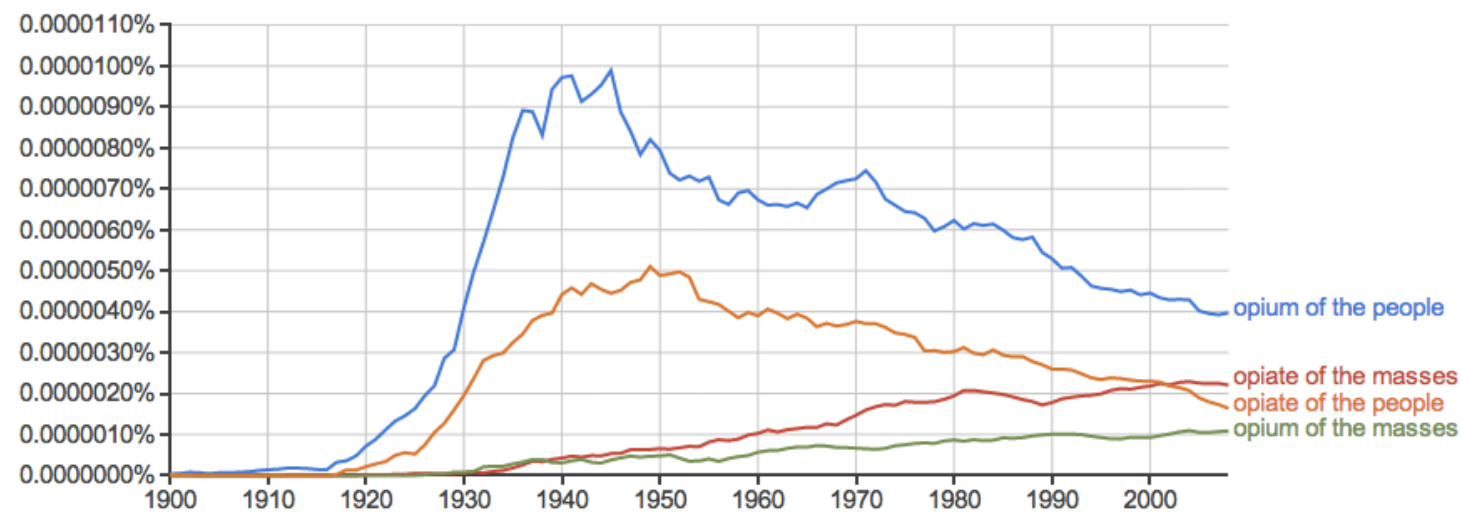

Figure 2: Google Ngram of "new opium of the people" and "another opium of the people," 1900-2010.

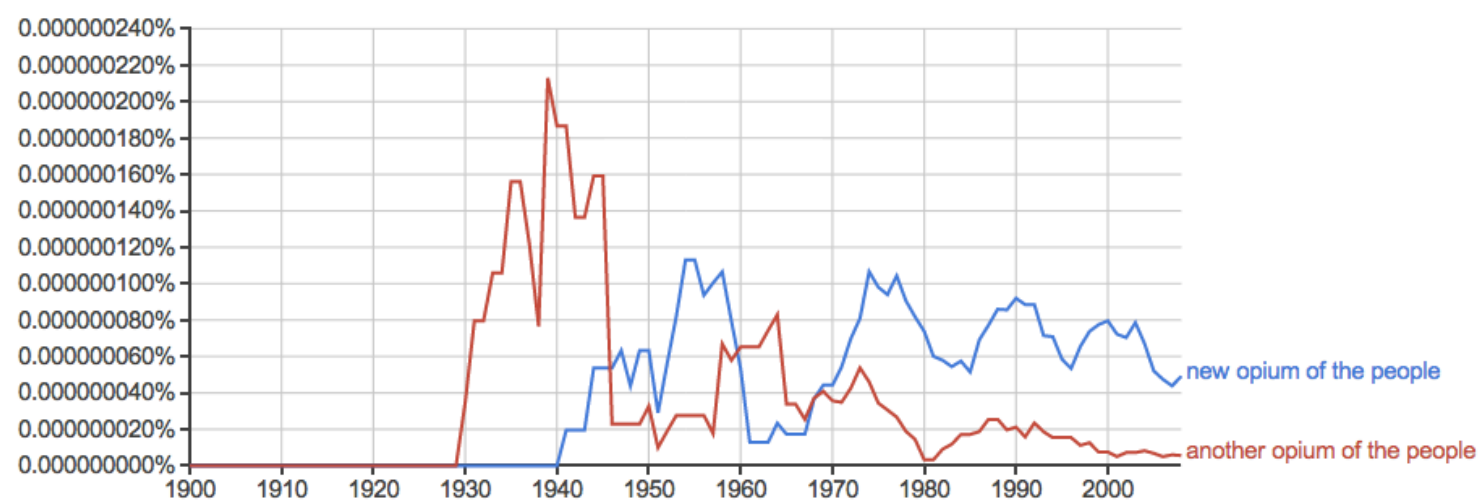


Figure 3: Google Ngram of "iron cage" and "bureaucratic rationality," 1930-2010.

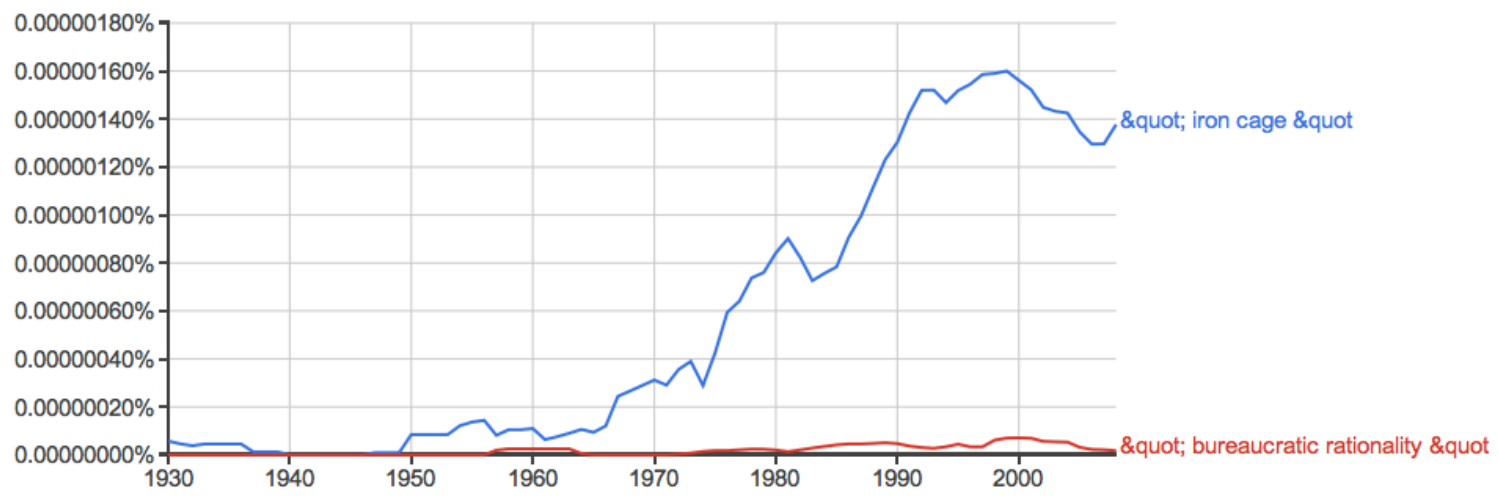

\footnotetext{
${ }^{1}$ We leave aside the subcategorization that has interested others, e.g. Perry 1993:1-4. See also Morson, who would classify what we are calling aphorisms as dicta. For him, dicta help simplify our understanding of the world while aphorisms "share a sense that that what is most valuable to grasp lies beyond our reach." (Morson 2004:260).

${ }^{2}$ It is also worth noting that many aphorisms are metaphors or similes, including two for which we provide a more in-depth analysis here (iron cage and opiate of the people). Yet, for the purposes of this paper, we bracket questions of the role of metaphor in argument and social science, which would be an entirely separate analysis and has, at any rate, been well examined elsewhere (Kuhn 1993; Sayer 1992:62-65; Ricoeur [1975] 2003). We instead focus on the role of the aphorism itself, even if we agree with Davis, in his study of aphorisms, that "the cognitive process that creates the most insightful thoughts and effective actions, is analogy" (1999:262, italics in original).

${ }^{3}$ These wisdom statements are taken from The Dictionary of Modern Proverbs (Doyle et al 2012).

${ }^{4}$ On this point, aphorisms operate analogously to scandals. The word scandal derives from "stumbling block": successful scandals like successful aphorisms are arresting and agentic. See Girard (1984), Adut (2008) and Crosbie (2015).

${ }^{5}$ The original full title is Réflections; ou, sentences et maximes morales, and it was originally published 1665 , and republished in slightly altered forms in 1665, 1666, 1671, 1675 and 1678 (quotations are taken from a translation based on the 1678 edition). Following convention, we use the shortened names of the writer and the work (La Rochefoucauld and Maximes respectively).

${ }^{6}$ These are more often called maxims in reference to La Rochefoucauld, although the terms are generally interchangeable. These should not be confused with "Reflections," a different genre in which La Rochefoucauld also distinguished himself. His Reflections are longer pieces, often resembling short prose poems or mini-essays.

${ }^{7}$ Wilkie (1976) argues that Marx's use of language was expressly intended to engineer a transformation of proletarian consciousness, actualized in part through painstaking research and in part through lofty rhetoric (including, as we have seen, the use of wisdom statements). González García (2011) has sketched the ways in which Weber drew from earlier generations of German Romantic poetry in the articulation of his ideas. ${ }^{8}$ Weber's saying first appeared as an essay in the publication Archiv für Sozialwissenshaft und Sozialpolitik, published in two parts in 1904 and 1905 (Swatos and Kaelber 2005:xiii). Several other pieces were added to the original text until, in 1920, Weber published most of the pieces together in what became the definitive imprint. The 1904-5 essay and 1920 book-length edition both bore the title "Die protestantische Ethik und der Geist des Kapitalismus," which we shorten here as The Protestant Ethic. ${ }^{9}$ A jstor.org search yielded 85 references to ["war made the state" OR "war makes the state"]. A Google Scholar search yielded 438 results for ["war made the state"] and 100 results for ["war makes the state"].
} 


\section{References}

Abbott Andrew. 2010. Chaos of Disciplines. Chicago: University of Chicago Press.

Adut Ari. 2008. On Scandal. Cambridge: Cambridge University Press.

Ahram Ariel I., and Charles King. 2012. "The warlord as arbitrageur." Theory and Society 41(2):169-186.

Appleby, Scott. 2000. The Ambivalence of the Sacred: Religion, Violence, and Reconciliation. Lanham, MD: Rowman \& Littlefield.

Bacon, Fracis. ([1620] 1999) The New Organon. In Francis Bacon: Selected Philosophical Works. Ed. Rose-Mary Sargent. Indianapolis, IN: Hackett.

Baehr, Peter. 2001. 'The 'iron cage' and the 'shell as hard as steel': Parsons, Weber, and the stahlhartes Gehäuse metaphor in The Protestant Ethic and the Spirit of Capitalism." History and Theory 40(2): 153-169.

Barthes, Roland. 1981 [2009]. "La Rochefoucauld: Reflections or sentences and maxims." In New Critical Essays, trans. Richard Howard. Evanston, IL: Northwestern University Press.

Basgöz, İlhan. 1993. Proverb image, proverb message, and social change. Journal of Folklore Research, 30(2/3): 127-142. 
Benjamin, Walter. [1972] 1999. The Arcades Project. trans. Howard Eiland and Kevin McLaughlin. Cambridge, MA: Belknap Press.

Berman Marshall. 1987. All That is Solid Melts into Air: The Experience of Modernity. New York: Verso.

Billings Dwight B. 1990. "Religion as opposition: A Gramscian analysis." American Journal of Sociology 96(1): 1-31.

Bloom Harold. 1983. Agon. New York: Oxford University Press.

Bloom Harold. 1975. A Map of Misreading. New York: Oxford University Press.

Bloom Harold. 1973. The Anxiety of Influence: A Theory of Poetry. New York: Oxford University Press.

Bortolini Matteo. 2012. "The trap of intellectual success: Robert N. Bellah, the American civil religion debate, and the sociology of knowledge." Theory and Society 41(2): $187-210$.

Bourdieu Pierre, and Loïc Wacquant. 1992. An Invitation to Reflexive Sociology. Chicago: University of Chicago Press.

Braddon-Mitchell, David. 2001. "Lossy laws." Nô̂s. 35(2):260-277.

Buroway Michael. 2003. "Revisits: An outline of a theory of reflexive ethnography." American Sociological Review 68(5):645-679. 
Coser Lewis. 1970. The Masters of Sociological Thought: Ideas in Historical and Social Context. New York: Harcourt Bruce Jovanovich.

Crosbie, Thomas. 2015. "Scandal and military mediatization." Media, War \& Conflict, 8(1):100-119.

Daniel, Jack L., Geneva Smitherman-Donaldson, and Milford A. Jeremiah.1987.

"Makin'a way outa no way: The proverb tradition in the Black experience." Journal of Black Studies 17(4):482-508.

Davis Murray S. 1999. “Aphorisms and clichés: The generation and dissipation of conceptual charisma." Annual Review of Sociology. 25:245-269.

DiMaggio Paul J., and Walter W. Powell. 1983. “The iron cage revisited: Institutional isomorphism and collective rationality in organizational fields.: American Sociological Review 48(2):147-160.

Doyle, Charles Clay, Wolfgang Mieder, and Fred R. Shapiro, eds. 2012. The dictionary of Modern Proverbs. New Haven: Yale University Press.

Eckberg Douglas Lee, and Lester Hill Jr, L. 1979. "The paradigm concept and sociology: A critical review." American Sociological Review 44(6):925-937.

Feldmann John, and John Kelsay. 1996. "Inside the iron cage: Notes on rationality and global capital markets.” Soundings: An Interdisciplinary Journal 79(3/4):385397.

Feldmann John, and John Kelsay. 1997. "Unlocking the iron cage: The hidden risks of formal rationality." Soundings: An Interdisciplinary Journal, 80(2/3):201-240. 
Foster John Bellamy, and Hannah Holleman. 2012. "Weber and the environment: Classical foundations for a postexemptionist sociology." American Journal of Sociology 117(6):1625-1673.

Franklin, Benjamin. [1733-1758] 2004. Poor Richard's Almanack. Andrew S. Trees (ed.). New York: Barnes and Noble Publishing.

Garfinkel Harold. 1996. "Ethnomethodology's program." Social Psychology Quarterly 59(1):5-21.

Gaukroger Stephen. 2001. Francis Bacon and the Transformation of Early-Modern Philosophy. New York: Cambridge University Press.

Girard, René (1984) "Scandal and the dance: Salome in the Gospel of Mark." New Literary History 15(2):311-324.

Gorski Philip. 2011. The Protestant Ethic Revisited. Philadelphia: Temple University Press.

Gross, Alan. 1990. The Rhetoric of Science Cambridge, MA: Harvard University Press.

Guhin, Jeffrey. 2014. "Religion as site rather than religion as category: On the sociology of religion's export problem." Sociology of Religion 75(4):579-593.

Heirich Max. 1977. "Change of heart: A test of some widely held theories about religious conversion." American Journal of Sociology 83(3):653-680.

Hjarvard Stig. 2008. "The mediatization of society: A theory of the media as agents of social and cultural change." Nordicom Review 29(2):105-134. 
Hoult, Thomas Ford. 1950. "Economic class consciousness in American Protestantism" American Sociological Review 15(1): 97-100.

Hurowitz Victor Avigdor. 2013 "Wisdom literature, Ancient Near East." The Encyclopedia of Ancient History. Malden, MA: Blackwell-Wiley.

Kitcher Philip.1995. “The Cognitive Function of Scientific Rhetoric.” In Krips, Henry, J.E. McGuire, J E, and Trevor Melia. Science, Reason, and Rhetoric Pp. 47-66. Pittsburgh: University of Pittsburgh Press.

Kuhn, Thomas S. 1993. "Metaphor in Science" in Ortony, Andrew. Metaphor and Thought. (pp. 533-542). New York: Cambridge University Press.

La Rochefoucauld F de ([1678] 1981) Maxims, trans. Leonard Tancock. New York: Penguin.

Manis Jerome G. and Bernard N. Meltzer. 1963. "Some correlates of class consciousness among textile workers." American Journal of Sociology 69(2):177-184.

Manzo, Silvia. 2006. Francis Bacon: Freedom, authority and science. British Journal for the History of Philosophy 14(2):245-273.

Marx Karl [1843] 1978a. "On the Jewish question.” In The Marx-Engels Reader. Tucker, Robert C. (ed.). New York: W. W. Norton \& Company.

Marx K [1843] 1978b. Contribution to the critique of Hegel's Philosophy of Right. In The Marx-Engels Reader. Tucker, Robert C. (ed.). New York: W. W. Norton \& Company. 
Marx K [1844] 1978c. Economic and philosophic manuscripts of 1844. In The MarxEngels Reader. Tucker, Robert C. (ed.). New York: W. W. Norton \& Company.

Marx K [1845-1846] 1978d. The German ideology. In The Marx-Engels Reader. Tucker, Robert C. (ed.). New York: W. W. Norton \& Company.

Marx K [1875] 1978e. Critique of the Gotha program. In The Marx-Engels Reader.

Tucker, Robert C. (ed.). New York: W. W. Norton \& Company.

Marx K [1888] 1978f. The Communist manifesto. In The Marx-Engels Reader. Tucker, Robert C. (ed.). New York: W. W. Norton \& Company.

Maxim [Def 2b] 1989. Oxford English Dictionary. Second Edition.

McKinnon Andrew M. 2005. "Reading 'Opium of the People': Expression, Protest, and the Dialectic of Religion." Critical Sociology 31(1-2):15-38.

Mitzman Arthur [1969] 2002. The Iron Cage: An Historical Interpretation of Max Weber. Piscataway, NJ: Transaction Publishers.

Morson Gary S. 2004. "The Rhetoric of the Aphorism" pp. 248-265. In Jost, Walter and Wendy Olmstead. (eds.) A Companion to Rhetoric and Malden, MA: Blackwell.

Nietzsche Friedrich. [1878] 1994. Human, All Too Human. trans. Marion Faber with S Stephen Lehmann. London: Penguin.

Norris, Pippa and Ronald Inglehart. 2004. Sacred and Secular: Religion and Politics Worldwide, New York: Cambridge University Press. 
Pascal, Blaise. [1669] 1995. Pensées, trans. A.J. Krailsheimer. New York: Penguin.

Pechenick, Eitan Adam, Christopher M. Danforth, and Peter Sheridan Dodds 2015.

"Characterizing the Google Books corpus: Strong limits to inferences of sociocultural and linguistic evolution." PloS one 10(10):e0137041.

Perry Thedor Anthony. 1993. Wisdom Literature and the Structure of Proverbs.

University Park, PA: The Pennsylvania State University Press.

Ricoeur Paul. [1975] 2003. The Rule of Metaphor: The Creation of Meaning in

Language. trans. R Czerny with K McLauglin and J Costello. New York:

Routledge Classics.

Sallaz Jeffrey J. (2012) Politics of organizational adornment: Lessons from Las Vegas and beyond. American Journal of Sociology, 77(1):99-119.

Sayer Andrew. 1992. Method in Social Science, $2^{\text {nd }}$ Edition. New York: Routledge.

Shapin, Steven. 1991. "'A Scholar and a Gentleman': the problematic identity of the scientific practitioner in early modern England." History of Science 29(3):279327.

Snider, Alvin. 1988. "Francis Bacon and the authority of the aphorism." Prose Studies11(2): 60-71.

Stark Rodney. 1964. "Class, radicalism, and religious involvement in Great Britain." American Sociological Review 29(5): 698-706. 
Steinmetz, George. 2005. (ed). The Politics of Method in the Human Sciences: Positivism and its Epistemological Others. Durham: Duke University Press.

Stephens James. 1970. “Science and the Aphorism: Bacon's Theory of the Philosophical Style." Communication Monographs 37(3):15-171.

Stephenson, R. H. 1980. "On the Widespread Use of an Inappropriate and Restrictive Model of the Literary Aphorism." The Modern Language Review 75(1):1-17.

Swatos, William H. Jr, and Lutz Kaelber. (2005) (eds.) The Protestant Ethic Turns 100: Essays on the Centenary of the Weber Thesis. Boulder: Paradigm Publishers.

Swedberg, Richard, and Wendelin Reich. 2010. "Georg Simmel's aphorisms.” Theory, Culture \& Society 27(1): 24-51.

Thomas, Paul. 1991, "Critical reception: Marx then and now." In The Cambridge Companion to Marx. T Carver (ed.). Pp. 23-54. Cambridge: Cambridge University Press.

Tilly Charles. 1975. The Formation of National States in Western Europe. Princeton: Princeton University Press.

Tilly, Charles. 1985. "War and state making as organized crime.” In P Evans, D Rueschemeyer, and T Skocpol (eds). Bringing the State Back In. pp. 169-191. Cambridge: Cambridge University Press.

Tilly, Charles. 1992. Coercion, Capital and European States, AD 990-1992. Cambridge: Blackwell. 
Weber Max. [1922] 1968. Economy and Society: An Outline of Interpretive Sociology. Guenther Roth and Claus Wittich (eds.). Berkeley: University of California Press.

Weber, Max. [1905] 1992. The Protestant Ethic and the Spirit of Capitalism, trans. Talcott Parsons. London: Routledge.

Weber Max. [1905] 2002. The Protestant Ethic and the "Spirit" of Capitalism and Other Writings, trans. Peter Baehr and Gordon C. Wells. New York: Penguin Books.

Weber M [1905] 2010. The Protestant Ethic \& the Spirit of Capitalism, trans. Stephen Kalberg. New York: Oxford University Press.

Weeks, Stuart. 2010. An Introduction to the Study of Wisdom Literature. New York: T\&T Clark.

White, Hayden. 1987. The Content of the Form. Baltimore: Johns Hopkins University Press.

Wood, Gordon S. 2005. The Americanization of Benjamin Franklin. New York: Penguin. 